\title{
Advance of the Chemical Components and Biological Activities of Ajuga Decumbens Thunb
}

\author{
Olagoke Zacchaeus Olatunde ${ }^{1}$, Yang Yang ${ }^{1,3}$, Jianping Yong*2, Canzhong $\mathrm{Lu}^{* 1,2}$ \\ ${ }^{1}$ Fujian Institute of Research on the Structure of Matter, Haixi Institute, Chinese Academy of Sciences, Fuzhou, 350002 \\ ${ }^{2}$ Xiamen Institute of Rare-earth Materials, Haixi Institute, Chinese Academy of Sciences, Xiamen, 361021 \\ ${ }^{3}$ ShanghaiTechUniversity, Shanghai, 201210
}

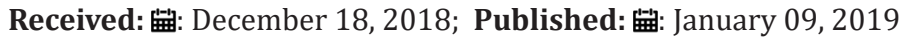

*Corresponding author: Jianping Yong, Xiamen Institute of Rare-earth Materials, Haxi Institute, Chinese Academy of Sciences, China Canzhong Lu, Fujian Institute of Research on the Structure of Matter, Haixi institute, Chinese Academy of Sciences, China

\begin{abstract}
Ajuga decumbens Thunb is an annual herbaceous flowering plant, distributed in some parts of Asia. It is adequately used as folk medicines for the treatment different ailments. It contained important bioactive compounds (diterpenoids, iridoid glycosides, phytoecdysteroids, flavonoids and sesquiterpenoids) which made it to possess a wide spectrum of biological activities such as anti-cancer, antioxidant, Antifeedant, antibacterial, anti-inflammatory, antihyperlipidemic, anti-cholinesterase and cytotoxicity activities. This review gives an update about its phytochemicals and biological activities.
\end{abstract}

Keywords: Ajuga decumbens Thunb; Chemical components; Biological activities anization

\section{Introduction}

The genus Ajuga, belongs to the family of Labiatae, commonly known as "Bugleweed or Ground pine" [1] which distributed mainly in the temperate regions Europe, Asia and Africa [2] where most its species can be found, but only two of Ajuga species are available in southeastern Australia [3-4]. Pharmacological studies revealed that Ajuga possessed, have been used as anti-inflammatory agents, anticancer, astringent, anthelmintic, hypoglycemic, febrifuge diuretic, insecticidal properties and antifungal [5-11]. Ajuga decumbens is used as a folk medicine for the treatment of all kinds of ailment in ancient, most especially in China and Japan [12-15]. This review shows previous research on bioactive compounds of A. decumbens and biological activities of both the extracts and isolated compounds from this medicinal plant.

\section{Distribution of A. decumbens}

A. decumbens commonly found in stream sides, wet grassy slopes in Anhui, Fujian, Guangdong, Hainan, Hubei, Hunan, Jiangsu, Jiangxi, Qinghai, Sichuan, Taiwan, Yunnan, Zhejiang of China and some parts in Japan and Korea [16].

\section{The Morphology of Ajuga decumbens Thunb}

A. decumbens is an annual herbaceous flowering plant, which grow to $10-30 \mathrm{~cm}$ height with white villous on the young parts of the stem, numerous basal leaves longer than stem leaves, floral leaves are bractlike and lanceolate, with funnel- shape calyx and corolla tubular, straight, basally slightly swollen. Flowering starts from March and lasts to the end of July. The fruiting season starts from May and continues till November [16].

\section{Bioactive Compounds Isolated from A. decumbens}

There are bioactive compounds isolated from A. decumbens, including diterpenoids, iridoid glycosides, triterpenoids, sesquiterpenoids, phytoecdysteroids, withanolides and other essential compounds, which are responsible for its effective biological activities.

Diterpenoids: $A$. decumbens is highly rich in diterpenoids as other Ajuga species, diterpenoids from A. decumbens are of two groups that are neoclerodane and abietane [11,17-18]. Eight diterpenoids were isolated from ethanol extract of $A$. decumbens, including Ajugacumbins A (1), Ajugacumbins B (2), Ajugacumbins C (3), Ajugacumbins D (4), Ajugamarins A2 (5), Ajugamarins G1(6), Ajugamarins H1(7) and Ajugamarins F4 (8) [19-20]. Min et al. also isolated Ajugacumbins E (9) and Ajugacumbins F (10) for the first time [21]. Ajugacumbins G (11) was isolated from A. decumbens [22]. Amano et al. isolated Ajugatakasins A (12), Ajugatakasins B (13), Ajugaside A (14), Ajugapitin (Clerodendrin D) (15) and Dihydroajugamarin (16) from the extract of A. decumbens [23]. 
Ajugacumbin $\mathrm{H}$ (17) was identified from the chloroform extracts of A. decumbens [24]. 15-epi-lupulin A (18), 6-0-deacetylajugamarin (19), Ajugadecumbenins A (20) and Ajugadecumbenins B (21) were discovered [25].

Ajugamarin A1 chlorhydrin (22) was isolated from the whole plant of $A$. decumbens [26]. Sun et al. also isolated ten neoclerodane diterpenoids, including $6 \alpha, 19-$ diacetoxy- $4 \alpha-$ hydroxy-1 $\beta$-tigloyloxyneo-clerod12-en-15-oic acid methyl ester-16-aldehyde (23), (12s)-18,19-diacetoxy-4 $\alpha, 6 \alpha, 12$ trihydroxy-1ßtigloyloxy-neo-clerod-13-en-15,16-olide (24), (12S)-1 $\alpha, 19$-epoxy-6 $\alpha, 18$-diacetoxy-4 $\alpha, 12$-dihydroxyneoclerod-13-en-15,16-olide (25), (12s)-6 $\alpha, 19$-diacetoxy-18 chloro-4 $\alpha$-hydroxy-12-tigloyloxy-neo-clerod-13-en-15,16-olide (26), (12s,2"s)-6 $\alpha, 19$-diacetoxy18-chloro-4 $\alpha$-hydroxy-12-(2methylbutanoyloxy)-neo-clerod-13-en-15,16-olide (27), $4 \alpha, 6 \alpha-$ dihydroxy-18-(4'-methoxy-4' -oxobutyryloxy)-19-tigloyloxy-neoclerod-13-en-15,16-olide (28), Ajugaciliatin J (29), Ajuganipponin B (30), Ajugamarin A1(31), Ajugarin I (32) [27-28]. Lv et al. reported Ajugacumbin J (33) as a new neo-clerodane diterpene [29]. Diglucopyranoside (34) and Ajugaside (14) were isolated from the whole plants of $A$. decumbens as a newly detected abietane [30]. Wang et al. isolated Ajudecumin A (35), Ajudecumin B (36), Ajudecumin C (37) and Ajudecumin D (38) as newly rearranged abietane hydroquinones, with Ajuforrestin A (39) and Ajuforrestin B (40) as known abietanes from the aerial parts of $A$. decumbens [18] (Figure 1).

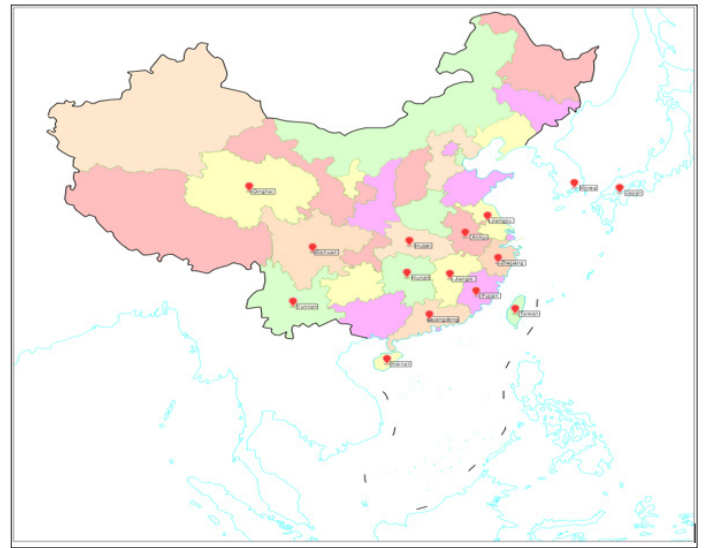

Figure 1: Distribution of $A$. decumbens.

Iridoid Glycosides: Iridoid glycosides are other predominant compounds of $A$. decumbens, Iridoid glycosides in plant contribute to defense against external factors such as herbivores or infection by microorganisms. Takeda et al., isolated Decumbeside A (41), Decumbeside B (42), Decumbeside C (43), Decumbeside D (44), reptoside (45) and 8-0 -Acetylharpagide (46) from Methanol extract of $A$. decumbens [31]. Three Iridoid glycosides were reported to be presence in A. decumbens out of seven compounds isolated and elucidated [30]. Wen et al., reported the contents of 8-0-acetylharpagide (46) and harpies (47) in A. decumbens by HPLC-ELSD [32] (Figure 2).

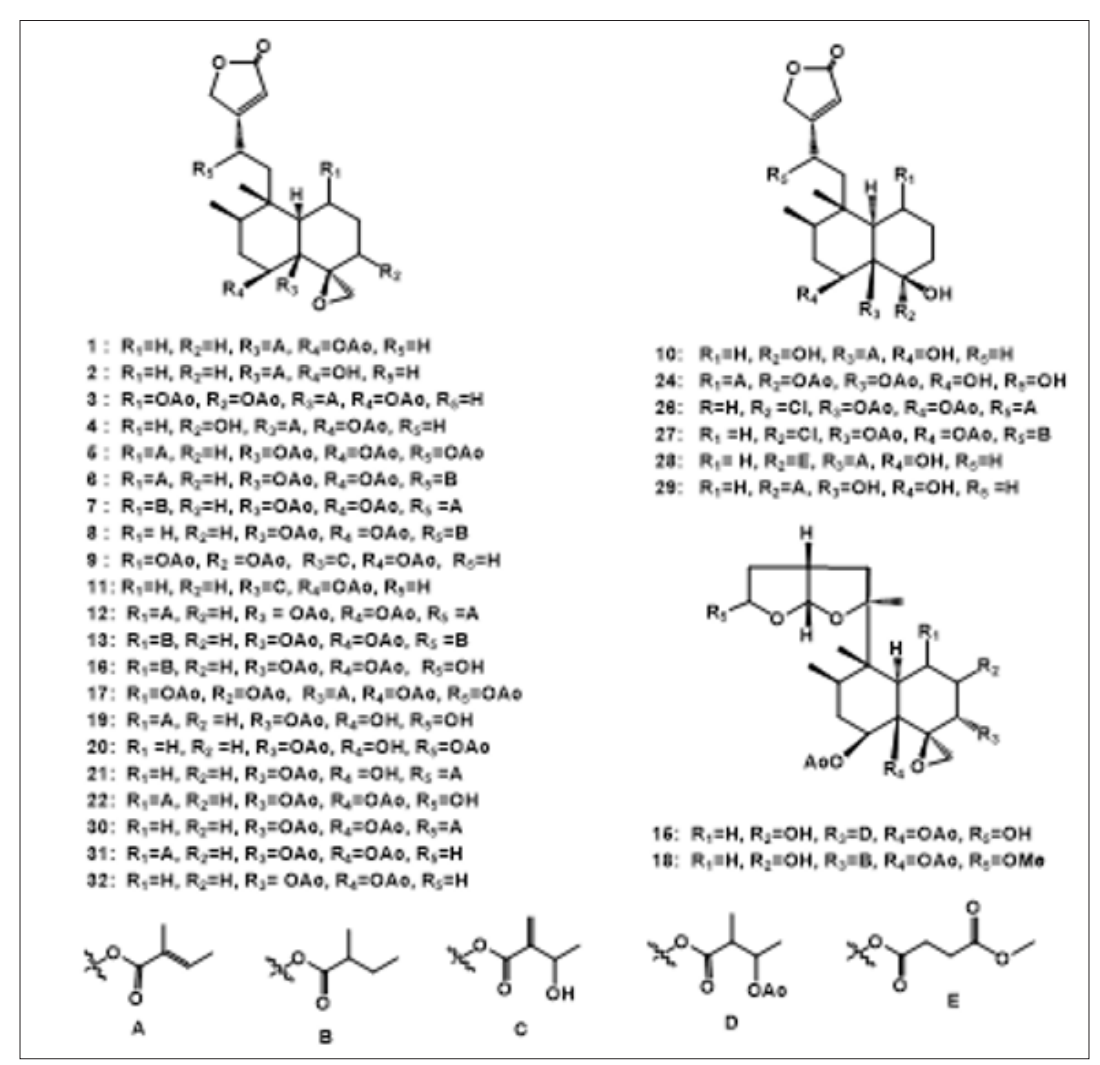

Figure 2. 
Phytoecdysteroids: Phytoecdysteroids are plant-derived cystoid's. Phytoecdysteroids are class of triterpenoids that plants synthesize for protection against phytophagous (plant eating) insects. Phytoecdysteroids were also presence in A. decumbens. Cymserine (48) and Ecdysterone (49) are usually the most abundant phytoecdysones in the genus Ajuga, were isolated from the whole part of this medicinal plant [33]. Koreeda et al. reported the presence Ajugalactone (50) from A. decumbens [34]. Eight phytoecdysteroids were also discovered from the plant [17]. Guo et al. Isolated $\beta$-sitosterol 3-0- $\beta$-D-glucopyranoside (51) from whole plant of A. decumbens [35] (Figure 3).

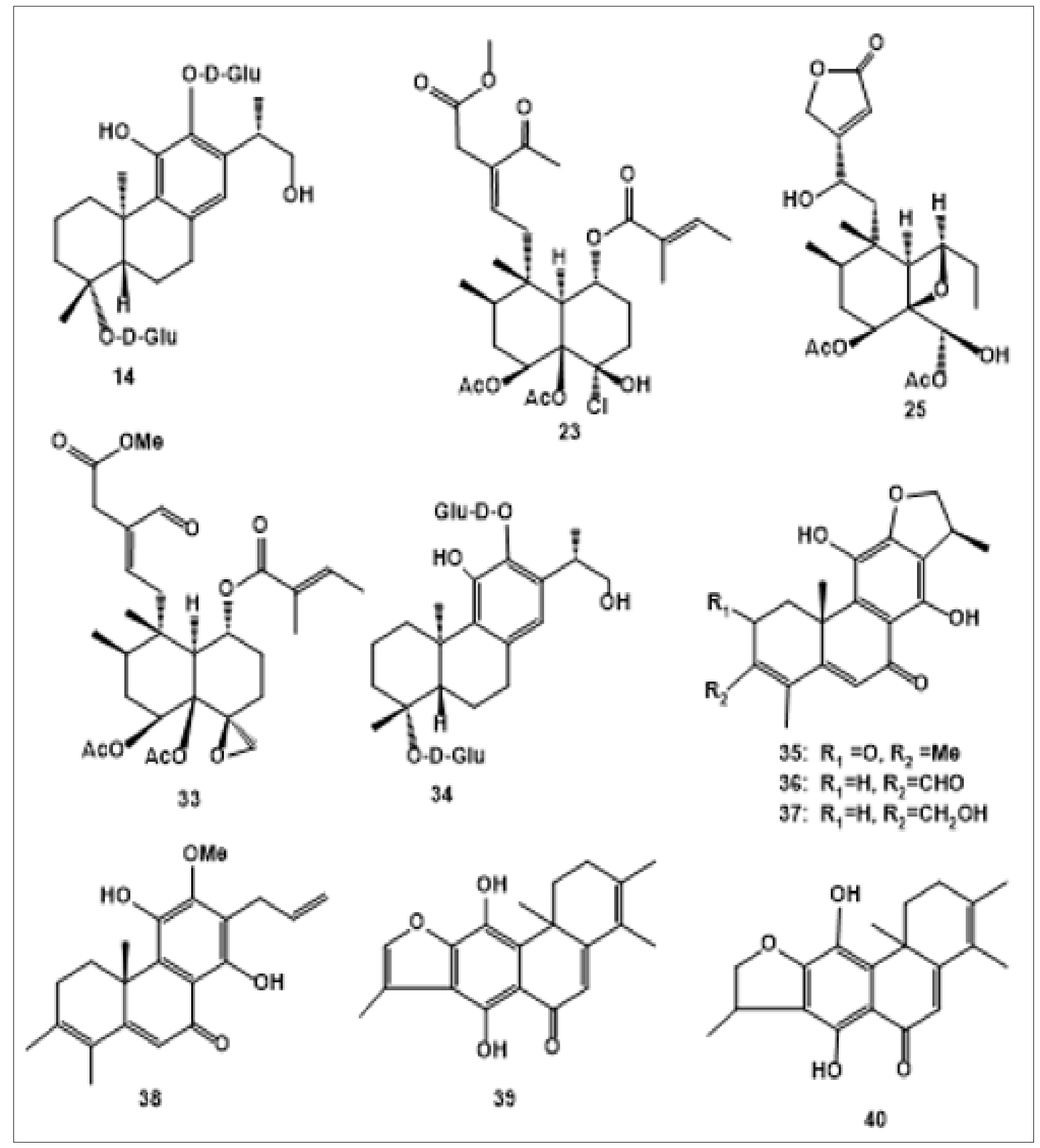

Figure 3.

Flavonoids: Studies have shown that various flavonoids are embedded in A. decumbens. Luteolin (52) was isolated from the ethanol extract of $A$. decumbens [36]. Guo et al., identified Dihydroxy-4-methyl flavone (53) from its methanol extract [35]. Api- genin (54) was reported be presence in A. decumbens [26]. Acacetin (55) was obtained from the aerial parts of this medicinal plant [18] (Figure 4). 


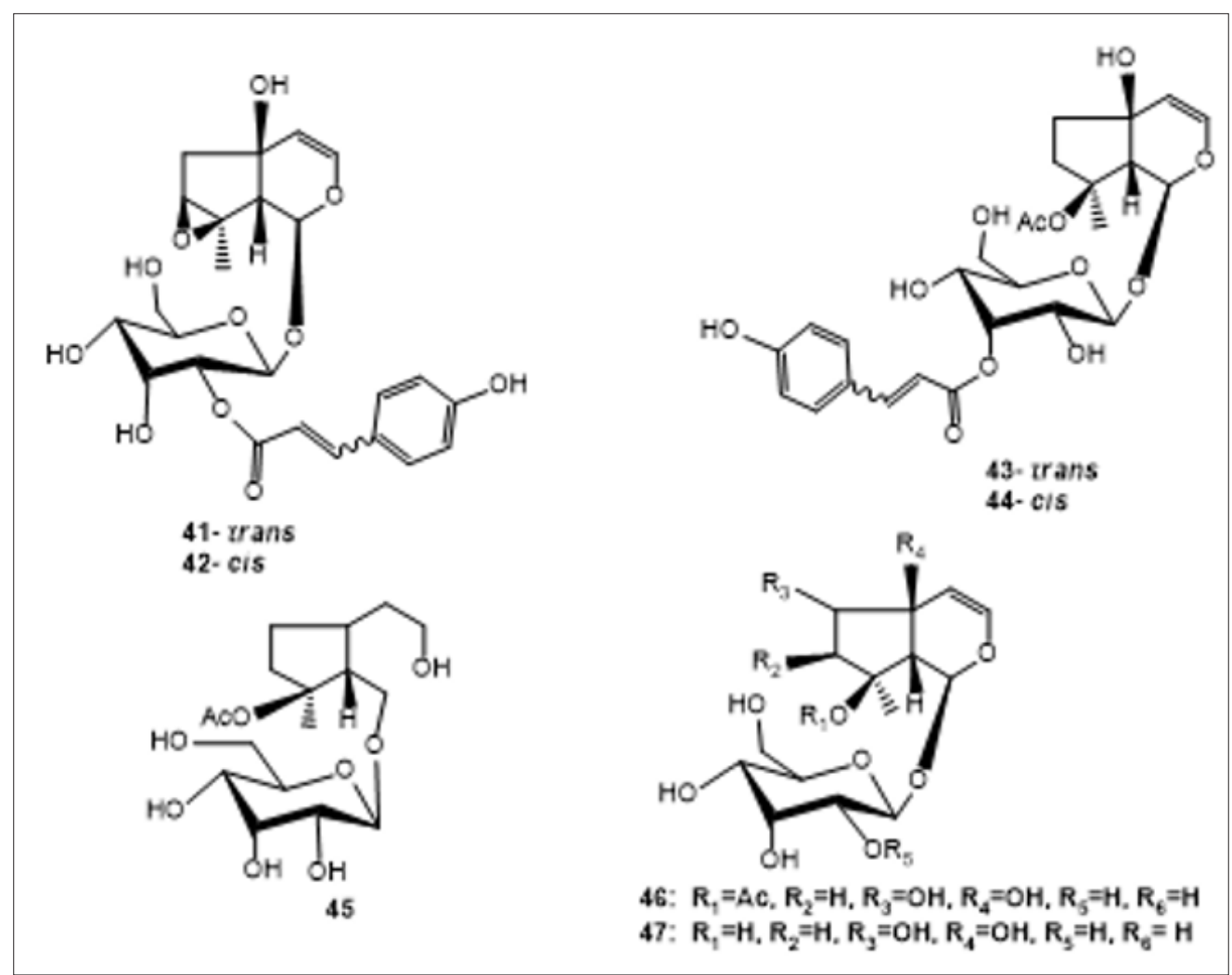

Figure 4 .

Sesquiterpenoids: Few of Sesquiterpenoids are reported, Glecholone (56), (6R,7E,9R)-9-Hydroxy-4,7-megastigmadien-3one(57), (3S,5R,6S,7E)-5,6-Epoxy-3-hydroxy-7-megastigmen-9one (58), (6E,9S)-9-Hydroxy-4,6-megastigmadien-3-one (59) and
6-Hydroxy-4,7-megastigmadiene-3,9-dione (60) were isolated from the aerial parts of $A$. decumbens [18]. Sun et al., Isolated Loliolide (61) from the whole plant of A. decumbens [26] (Figure 5).

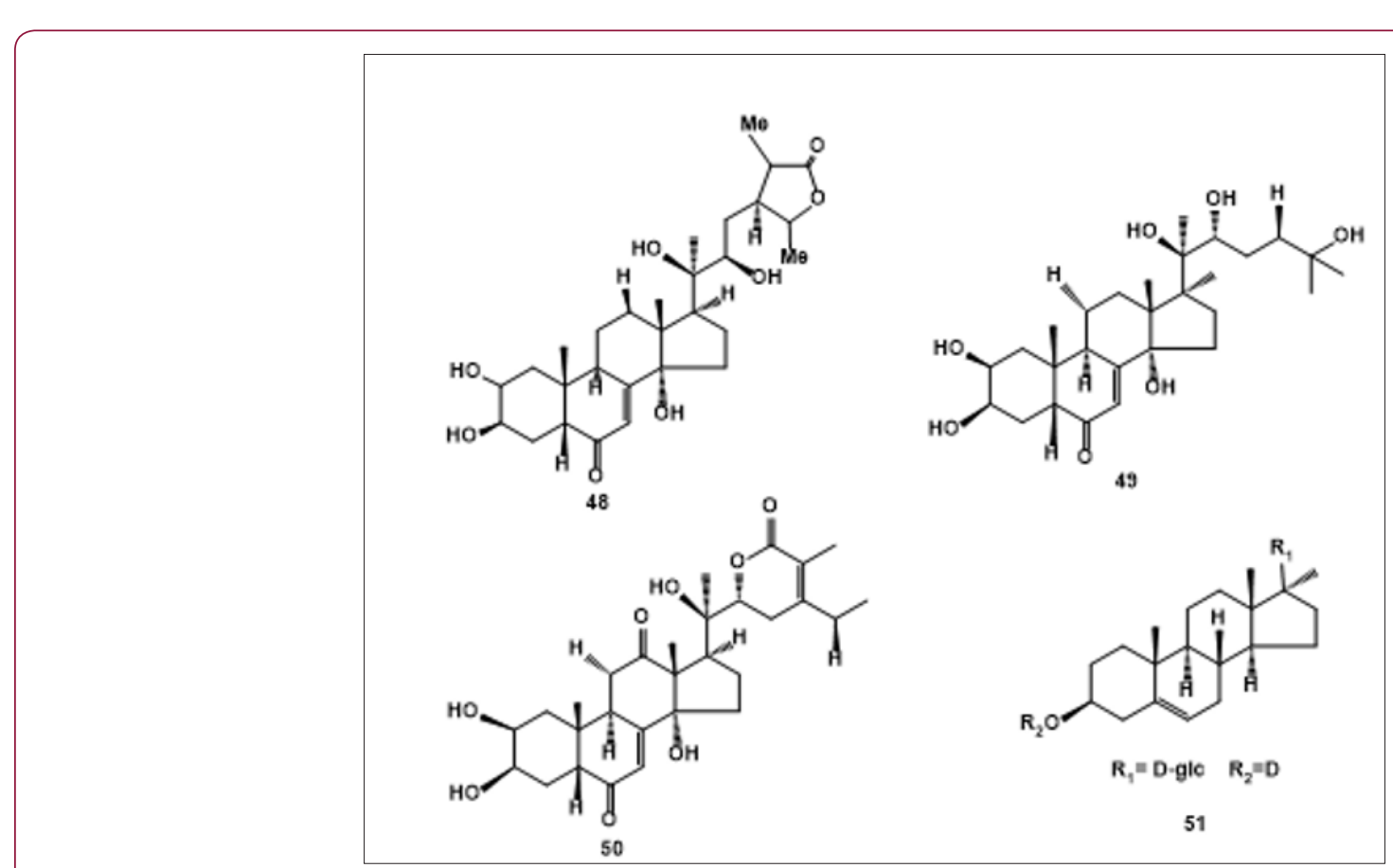

Figure 5. 


\section{Biological Activities}

Anti-Cancer Activity: Takasaki et al. conducted in vitro inhibitory effects of the isolated compounds (Ajugaside A (14), Reptoside (45), 8-0-acetylharpagide (46), Harpagide (47), Galactosylmartynoside (62), Martynoside (63) and Darendoside B (64) on Activation of the Epstein-Barr virus transcription factor BZLF1 by 12-0-tetradecanoylphorbol-13-acetate induced phosphorylation were evaluated, the results revealed that 8-0-Acetylharpagide (46) displayed the strongest inhibitory effect on EBV activation induced by TPA [27-30]. 8-0-acetylharpagide (46) also displayed inhibitory effect on hepatic carcinogenesis using $\mathrm{N}$-nitrosodiethylamine (DEN) as an initiator and phenol-barbital (PB) as a promoter [31-37]. Extracts of A. decumbens displayed anticancer and antimetastatic effects towards breast cancer through regulating the expression of MMPs and TIMPs [38]. Ajudecumin A
(35), Ajudecumin B (36) and Ajudecumin C (37) showed inhibitory effect on the proliferation of human breast cancer MCF-7 cells [18]. High and moderate dosage of total flavonoid of A. decumbens significantly lower the expression of serum Interleukin-1(IL-1) and Tumor necrosis factor alpha (TNF- $\alpha$ ), When compared with control [39]. Water extracts of $A$. decumbens significantly inhibited the increase of HepG2 cells in a dose-dependent manner [40]. Wang et al., reported that A. decumbens combined with Poria cocos have the ability to inhibit breast cancer cell invasion by targeting the expression of Mitogen-activated protein kinase (MAPK) and Epithelial-Mesenchymal Transition [41]. Iridoid in A. decumbens was investigated on the metastasis of invasive breast cancer cells and its related mechanism. The result showed that A. decumbens inhibited breast cancer cell invasion by suppressing the MAPK/ERK pathway as well as reversing the EMT $[42,43]$ (Figure 6).<smiles>[R]c1ccc(-c2oc3cc([R])c([R2])c([R])c3c(=O)c2[R4])cc1[R5]</smiles>

52: $\mathbf{R}_{1}=\mathrm{OH}, \mathbf{R}_{2}=\mathrm{H}, \mathbf{R}_{3}=\mathrm{OH}, \mathbf{R}_{4}=\mathrm{H}_{2} \mathbf{R}_{5}=\mathrm{OH}, \mathbf{R}_{6}=\mathrm{OH}$

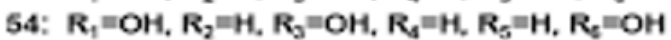

55: $\mathbf{R}_{1}=\mathrm{OH}, \mathbf{R}_{2}=\mathrm{H}, \mathbf{R}_{5}=\mathrm{OH}, \mathbf{R}_{4}=\mathrm{H}_{2} \mathbf{R}_{5}=\mathrm{H}, \mathbf{R}_{6}=\mathrm{OM}$<smiles>COc1ccc(-c2cc(=O)c3c(O)cc(O)cc3o2)cc1</smiles>

53

Figure 6.

Antifeedant Activity: Ajugapitin (15) which is also known as Clerodendrin D was discovered from the leaves of A. decumbens as a feeding stimulant for Athalia rosae ruficornis [23]. Min et al. isolated four Diterpenoids (Ajugacumbins A, B, C and D) from the ethanol extract of $\mathrm{A}$. decumbens, these isolated compounds displayed inhibition against the growth of insects [19]. Ajugacumbins E (9) and Ajugacumbins F (10) from A. decumbens showed insecticidal activities [21]. Ajugacumbins G (11) from this plant also exhibited growth-inhibitory activities against insects [22] (Figure 7).

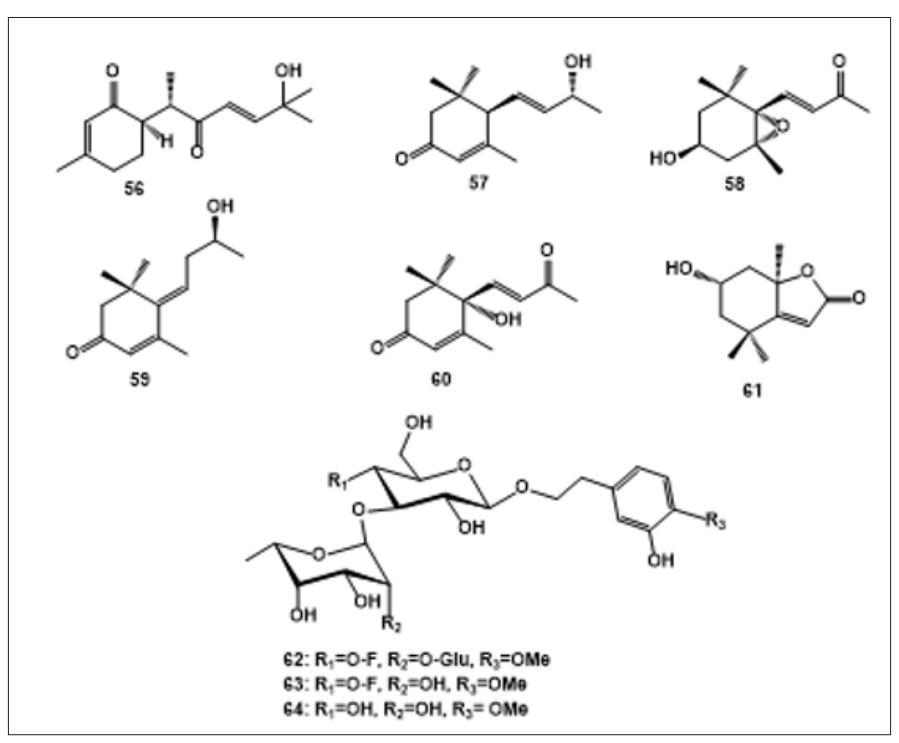

Figure 7. 
Anti-Inflammatory Activity: Ajugacumbin J (33) and Ajugacumbin D (4) isolated from the whole plant medicinal plant exhibited inhibitory activities of lipopolysaccharide-induced nitric oxide production in RAW 264.7 macrophages with IC50 s of 46.2 and $35.9 \mathrm{mM}$, respectively [29]. Ono et al. examined the effects of ethanolic extracts of $A$. decumbens on nitric oxide (NO) production, expression of inducible nitric oxide synthase (iNOS), osteoblast and osteoclast activities. The results showed that ethanolic extracts inhibited expression of iNOS which caused concentration dependent inhibition of NO production, prevented brittle bones in ovariectomized mice and swelling of the left hind ankle in adjuvant induced arthritic rats [14] (Table 1).

Table 1: Scientific Classification of Ajuga decumbens [16].

\begin{tabular}{|c|c|}
\hline Kingdom & Plantae \\
\hline Phylum & Tracheophyta \\
\hline Class & Magnoliopsida \\
\hline Order & Lamiales \\
\hline Family & Lamiaceae \\
\hline Genus & Ajuga \\
\hline Species & Decumbens \\
\hline
\end{tabular}

Anti-hyperlipidemic Effect: Xiaoming et al. reported that both the water and alcohol extracts of A. decumbens significantly showed reduction in the lipid levels in the blood, by administering the extracts on hyerlipemia mouse model [44].

Antivirus Activity: Takasaki et al. reported that 8-acetylharpagide (46) among other compounds isolated from the whole plant of $A$. decumbens showed the strongest inhibitory effect on Epstein-Barr virus activation induced by 12-0-tetradecanoylphorbol-13-acetate [30]. Water extract of A. decembens at the range of $750-1500 \mathrm{mg} / \mathrm{ml}$ concentrations exhibited in vitro inhibition on infectious Bronchitis virus [45]. Extract from the whole plant of A decumens possessed potent antiviral activities against respiratory syncytial virus (RSV) with IC50 of $131.6 \mu \mathrm{g} / \mathrm{ml}$ [46].

Antibacterial Activity: All doses of the extract of A. decumbens inhibited the growth Staphylococcus aureus, S. epidermis, Klebsiella pneumonia, Escherichia coli and Pseudomonas aeruginosa, but low dose was not as effective as Reyanning which a control was [47]. Water extract of A. decumbens possessed antibacterial activities against Streptococci, when analyzed its antibacterial activity in vivo and in vitro [48].

Cytotoxicity: Isolated diterpenoids from A. decumbens such as Ajudecumin A (35), Ajudecumin B(36), Ajudecumin C (37) and Ajudecumin D (38) were tested in vitro inhibition of cell proliferation. The results showed that Ajudecumin A (35) and Ajudecumin C (37) exhibited moderate cytotoxic activities against MCF-7 cell lines with IC50 values of 19.4 and $12.5 \mu \mathrm{M}$, respectively [18]. Myrotheciumone A isolated from endophytic fungus of $\mathrm{A}$. decumbens exhibited in vitro cytotoxicity and apoptosic activity [49].

Anti-cholinesterase Activity: $\mathrm{Xu}$ et al. reported that ethylacetate extract of A. decumbens showed high inhibition to acetylcholinesterase with IC50 of $0.0997 \mathrm{mg} / \mathrm{mL}$, it was concluded that the inhibition was possibly due to the flavonoids, which exist as the main chemical composition in A. decumbens [50].

Antioxidant Activity: decumbens showed the therapeutic effects on Mesangial Proliferative Glomerulonephritis (MsPGN) in rats, by reducing the urinary protein in the rats when it was compared with Triptergium Wilfordii Polyglycosidium (TWP) group [51]. Nan also reported that total flavonoids of A. decumbens reduced the damage of free radicals by increasing Superoxide dismutase (SOD), lowering malondialdehyde (MDA) and inhibition of lipid peroxidation of the induced chronic serum sickness glomerulonephritis rats [52].

\section{Conclusion and Future Perspectives}

A. decumbens is extensively used as traditional medicine for curing different ailments. Previous studies showed that both the isolated compounds and extracts possessed a wide spectrum of biological activities, such as anti-cancer, antioxidant, antifeedant, antibacterial, anti-inflammatory, antihyperlipidemic, anticholinesterase and cytotoxicity activities. All these pharmaco dynamic basis supported the use of $A$. decumbens as traditional medicines. However, although some structures of compounds were isolated and the relevant biological activities were tested, more compounds can be discovered and the medicinal values also need to be examined, such as analgesic, anthelmintic, cardioprotective and hypoglycaemic effects. In vivo experiments and toxicity of isolated bioactive compound and extracts should be overemphasized in order to be saved from consumptions. Researchers should focus on identification and quantification the bioactive compounds responsible for each biological activity that $A$. decumbens displays. There should adequate studies on elucidation of the molecular mechanisms underlying the activity of these bioactive compounds, which can lead to use of this plant extracts for drug development.

\section{Acknowledgement}

This work was financially supported by the National Natural Science Foundation of China (21875252) and the Project of The Plan of Xiamen Science and Technology (3502ZCQ20171000).

\section{References}

1. Bailey LH, Bailey EZ (1976) The staff of the Liberty Hyde Bailey Hortorium Hortus third: A concise dictionary of plants cultivated in the United States and Canada. Macmillan New York, USA.

2. Ajuga Flora of China. 17: 63.

3. Govaerts R, Ajuga L (1995) World Checklist of Seed Plants. MIM Deurne 1(1, 2): 1-483, 1-529.

4. Govaerts R, Ajuga (2003) World Checklist of Selected Plant Families Database in ACCESS: 1-216203. The Board of Trustees of the Royal Botanic Gardens, Kew, UK.

5. Cocquyt K, Cos P, Herdewijn P, Maes L, Van den Steen PE, et al. (2011) Ajuga remota Benth: from ethnopharmacology to phytomedical perspective in the treatment of malaria. Phytomedicine 18(14): 12291237.

6. Makni M, Haddar A, Kriaa W, Najiba Zeghal (2013) Antioxidant, free radical scavenging, and antimicrobial activities of Ajuga ivaleaf extracts. Int J Food Prop 16(4): 756-765. 
7. Mamadalieva NZ, El Readi MZ, Ovidi E, Micheal Wink (2013) Antiproliferative, antimicrobial and antioxidant activities of the chemical constituents of Ajuga turkestanica. Phy-topharmacology 4: 1-18.

8. Ni B, Dong X, Fu J, X Yin, L Lin, et al. (2015) Phytochemical and biological properties of Ajuga decumbens(Labiatae): a review. Trop J Pharm Res 14: 1525-1536.

9. Atay I, Kirmizibekmez H, Kaiser M, Akaydin G, Yesilada E, et al. (2016) Evaluation of in vitro antiprotozoal activity of Ajuga laxmannii and its secondary metabolites. Pharm Biol 54: 1808-1814.

10. Kayani WK, Dilshad E, Ahmed T, Ismail H, Mirza B (2016) Evaluation ofAjuga bracteosafor antioxidant, anti-in-flammatory, analgesic, antidepressant and anticoagulant activities. BMC Complement Altern Med 16: 375 .

11. Qing X, Yan HM, Ni ZY, Christopher JV, Man-Li Z, et al. (2017) Chemical and pharmacological research on the plants from genus Ajuga, Heterocycl. Commun 23(4): 245-268.

12. Konoshima M, Shibata S, Shimomura T (1963) Yakuyo Shokubutu Daijiten Hirokawa Publishing Co pp. 111.

13. (1986) Jiangsu New Medical College, Dictionary of Chinese Materia Medica. Shanghai: People's Publishing House 75.

14. Ono Y, Fukaya Y, Imai S, Yamakuni T (2008) Beneficial effects of Ajuga decumbens on osteoporosis and arthritis. Biol Pharm Bull 31: 11991204.

15. Zhang LQ, Feng L, Jia Q, Xu J, Wang R, et al. (2011) Effects of $\beta$-glucosidase hydrolyzed products of harpagide and harpagoside on cyclooxygenase2(COX-2) in vitro. Bio Med Chem 19: 4882-4886.

16. Huxley A (1992) The New RHS Dictionary of Gardening 1992, Macmillan Press ISBN: 0-333-47494-5.

17. Takasaki M, Tokuda H, Nishino H, Takao K (1999) Cancer chemopreventive agents (antitumor-promoters) from Ajuga decumbens. J Nat Prod 62: 972-975.

18. Wang L, Lu W, Shen Q, Wang S, Zhou H, et al. (2012) Simultaneous determination of imperatorin and its 2 metabolites in dog plasma by using liquid chromatography-tandem mass spectrometry. J Pharmaceut Biomed 70: 640-646.

19. Min ZD, Wang SQ, Zheng QT, Binrg WU, Mizuo Mizuno, et al. (1989) Four new insect antifeedant neo-clerodane diterpenoids, ajugacumbins $\mathrm{A}, \mathrm{B}$ C and D, from Ajuga decumbens. Chem Pharma Bull 37: 2505-2508.

20. Shimomura H, Sashida Y, Ogawa K (1989) Neo-Clerodane diterpenes from Ajuga decumbens. Chem Pharma Bull 37: 996-998.

21. Min ZD, Mizuno M, Wang SQ (1990) Two new neo-clerodane diterpenes in Ajuga decumbens. Chem Pharma Bull 38: 3167-3168.

22. Chen HM, Min ZD, Iinuma M, Tanaka T (1995) Clerodane diterpenoids from Ajuga decumbens. Chem Pharma Bull 43: 2253-2255.

23. Amano T, Nishida R, Kuwahara Y (1997) Ajugatakasins A and B, new diterpenoids from Ajuga decumbens, and feeding stimulative activity of related neoclerodane analogs toward the turnip sawfly. Biosci Biotech Bioch 61: 1518-1522.

24. Sang JS, Huang ZH, Min ZD (2005) A New neo-Clerodane Diterpene Isolated from Ajuga decumbens. Chin J Nat Med 3: 284-286.

25. Huang XC, Qin S, Guo YW, Karsten K (2008) Four New Neoclerodane Diterpenoids from Ajuga decumbens. Helvetica Chimica Acta 91: 628634.

26. Sun ZP, Gui LP, Guo YQ XU Jing, LI Yu shan, et al. (2012) Isolation and identification of chemical constituents from the whole plants of Ajuga decumbens. J Shenyang Pharm Univy 29: 758-760.

27. Sun ZP, Li YS, Jin DQ Guo P, Song H, et al. (2012) Neo-Clerodane diterpenes from Ajuga decumbens and their inhibitory activities on LPS induced NO production. Fitoterapia 83: 1409- 1414.
28. Sun ZP, Li Y, Jin DQ, Guo P, Xu J, et al. (2012) Structure Elucidation and Inhibitory Effects on NO Production of Clerodane Diterpenes from Ajuga decumbens. Planta Med 78: 1579-1593.

29. Lv H, Luo J, Kong L (2014) A new neo-clerodane diterpene from Ajuga decumbens. Nat Pro Res 28: 196-200.

30. Takasaki M, Yamauchi I, Haruna M, Takao T (1998) New glycosides from Ajuga decumbens. J Nat Prod 61: 1105-1109.

31. Takeda Y, Tsuchida S, Fujita T (1987) Four new iridoid glucoside p-coumaroyl esters from Ajuga decumbens. Phytochemistry 26: 23032306.

32. Wen BY, Li JR (2014) Simultaneous Determination of 8-O-acetylharpagide and Harpagide in Ajuga decumbens Thunb. by HPLC-ELSD. Chinese Journal of Information on TCM 21(7): 89-92.

33. Imai S, Toyosato T, Sakai M, Yasuo Sato (1969) Isolation of cyasterone and ecdysterone from plant materials. Chem Pharm Bull 17: 340-342.

34. Koreeda M, Nakanishi K, Goto M (1970) Ajugalactone, an insect moulting inhibitor as tested by the Chilo dipping method. J Amer Chem Soc 92: 7512-7513.

35. Guo X, Huang Z, Bao Y (2005) Isolation and structure identification of chemical constituents in Ajuga decumbens. Zhongcaoyao 36: 646-648.

36. Jin JS, Dou SH (1994) Study on the flavonoids of Ajuga decumbens. Anhui Med J 15: 51.

37. Konoshima T, Takasaki M, Tokuda H, Nishino H (2000) Cancer chemopreventive activity of an iridoid glycoside, 8-acetylharpagide from Ajuga decumbens. Cancer Lett 57: 87-92.

38. Peng B, He R, Xu QH, Gao J, Lu Y, et al. (2011) Correlation between antimetastatic action of Ajuga decumbens and expression of MMPs and TIMPs. China J Chinese Materia Medica 36: 3511-3513.

39. Peng W, Nan L, Jia R (2013) Experimental effects of Flovonids Ajuga on Interleukin-1 and Tumor necrosis factor alpha (TNF- $\alpha$ ), in Merangial proliferative Glomerulonephrities rat. Chinese Archives of Traditional Chinese Medicine 31(7): 1627-1630.

40. Zhang XX, Wu J, Li D (2013) Effects of Ajuga Decumbens Thunb on Liver Carcinoma Cells in vitro and in vivo. J Liaoning Univ Tradit Chinese Med M 15: 58-61.

41. Wang JJ, Peng B, He R, QH Xu (2017) Preliminary research on effect of combination of Ajuga decumbens snd Poria cocos on invasion and metastasis of breast cancer, Chinese Pharmacological Bulletin 33(4): 581-588.

42. Peng B, Yang YF, Wang JJ, QH Xu (2017) Inhibitory effect of Ajuga decumbens Iridoids on the Metastasis of Triple Negative Breast Cancer and its Related Mechanism. Chin Pharm J 52(21): 1903-1908.

43. Peng B, He R, Han JY (2017) Intervention Effect of Ajuga decumbens Iridoids on Characteristics of Breaast cancer stem cells via MAPK/ERK and P13K/AKt signaling pathways. Chinese Journal of Experimental Traditional Medical Formulae 23(13): 94-99.

44. Xiaoming C, Yun L, Bo M (2012) Antihyperlipidemic effect of $A$. decumbens extracts, China Pharmaceutical 21(15): 1-7.

45. Luo MC, Zheng XF, Fan XP (2009) In vitro Inhibition of Infectious Bronchitis Virus by Ciliate Bugle Herb (Jin Gu Cao). J Longyan Univ 27: 77-79.

46. Ma SC, Du J, But PPH, Deng XL, Zhang YW, et al. (2002) Antiviral Chinese medicinal herbs against respiratory syncytial virus. J Ethnopharmacol 79: 205-211.

47. Zhang B, Zeng FJ, Zhang XY (2014) Study on anti- infection effect of Ajuga. Chin J Nosocomiol 24(12): 2937-2939.

48. Li M, Peng WH (2017) Chemical constituents and pharmacological research progress of Ajuga decumbens. J pr tradit Chinese mede 28: 322-323. 
49. Lin T, Wang G, Shan W, Dequan Z, Rong D, et al. (2014) Myrotheciumones Bicyclic cytotoxic lactones isolated from an endophytic fungus of Ajuga decumbens. Bioorg Med Chem Lett 24: 2504-2507.

50. Xu Y, Fang J, Yu C (2013) Inhibition Fractions and compounds from Ajuga decumbens on Acetylcholinesterase Activity. Chinese Archives of Traditional Chinese medicine 31(3): 565-566.

\section{ISSN: 2574-1241}

DOI: $10.26717 / B J S T R .2019 .12 .002314$

Jianping Yong. Biomed J Sci \& Tech Res

(c) (P) This work is licensed under Creative

Submission Link: https://biomedres.us/submit-manuscript.php
51. Nan LH, Peng WH, Fang TH (2009) Effects of Herba Ajuga on the improved Chronic serum sickness rats of Mesangial Proliferative Glomerulonephritis, Chinese Archives of Traditional Chinese Medicine 27(11): 2366-2368.

52. Nan L, Peng W, Zheng S (2009) Experimental effects of study of Total flavonoids of Ajuga on free radical damage in Chronic serum sickness glomerulonephritis rats, CJITWN 10(10): 867-870.

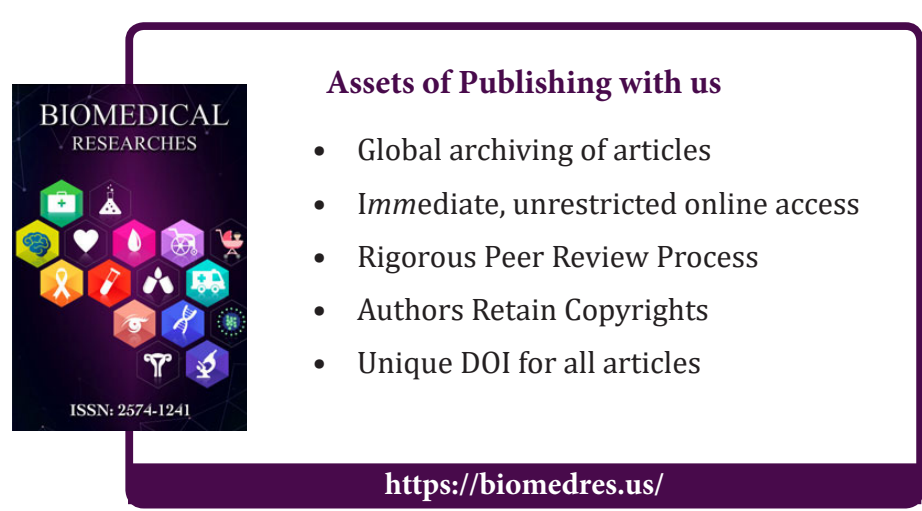

